\title{
Creativity, Covenant, and Christ
}

\author{
Brandon Gallaher
}

"GOD IS WITH US" (Isa. 8:10). These comfortable words, that comfortable name, "Immanuel" (Matt. 1:23; Isa. 7:14) (Hebrew, "God is with us"), Jesus Christ, are words Christians cannot say without fear and trembling, without a hearty gratitude for God's awesome grace revealed in creation through Christ, who is the King before the ages and who has wrought salvation in the midst of the earth (Ps. 74:12). For in Christ, through Christ, and by Christ, in the Christian understanding, we have God, we know God, and we and all creation with us are lifted up, illumined, and become grateful sons of God by the Son of His glory. Creation and the covenant in Christ, which is the subject of this study, are the means by which Christians think together God's loving and transformative relationship with His creation and human action within it.

In offering a Christian perspective on the place of humanity within God's creation, I shall begin with the beginning of all things - with creation as a divine gift. From there, I shall turn to the issue of covenant and its relationship to creation. On this basis, we shall then consider the Christian understanding of the uniqueness of humanity and how this is expressed through humanity (man and woman) being created in the image of God. I will then speak to how this relates to Jesus, who is understood as the "image of the invisible God" (Col. 1:15); the one in whom all things were created and the mediator and reconciler of all things with God. I will argue that the image of God, from a Christian perspective, speaks to the mediatorial vocation of humanity. Mediation, I will contend, is humanity's participation in divine creation through harmonizing the divisions that exist in creation. This mediation has a vehicle: obedient praise or glorification of God with the offering up of the self as pure and willing sacrifice through a holy life. Humanity turned from this call in the Fall, but the belief is that in Jesus it is reattained and the Christian Church is called to be the embodiment of 
this call and gift insofar as Christians are called to be a "royal priesthood, a holy nation" (1 Pet. 2:9; cf. Exod. 19:6). This is not the vocation of slaves but of those who are the "children of God" (1 John 3:1). In praising God, humanity is believed to transfigure and sanctify the world. But this also implies care and right stewardship of creation. Humanity "works" the world so that its first fruits might be offered up to God in thankfulness. Furthermore, the human being is called to work their individual lives in the cultivation of virtue (Col. 3:12-17). The modern world, instead of caring for creation and obeying its Creator by living lives of holiness and gratitude, has turned toward creation in greedy consumption. The Christian perspective is that only through once more beginning to see creation as a theophany of God's glory and our lives as pure offerings of gratitude to God can we attune ourselves with the creative Word of God. In my effort here, I must be necessarily selective. I will draw on a variety of Christian traditions, but it will also reflect my own interests as a theologian. I am also, it should be said, presenting a theological ideal. Individual Christians and institutions have very rarely lived up to it.

\section{Creation as a Divine Gift of Love}

In speaking of creation as a divine gift, we must say that, if it is a gift, then it comes from a gift giver who gifts it from love. God, in the Christian understanding, did not simply awake one day and arbitrarily create the world. The world is not the action of caprice. God is a God who takes joy in Himself. This is sometimes expressed by Christian theologians by saying poetically that the divine hypostases or persons of the Trinity (Father, Son, and Holy Spirit) — with "hypostasis" in no way being understood as an "individual"-fully and completely pour out themselves to one another in love. This divine love, it is claimed, then bubbles up and spills, as it were, into the world in the act of creation. Meister Eckhart (c. 1260-1328) even goes so far as to identify the very love God has for Himself with His love for creatures:

God loves Himself and His nature, His being and His Godhead. In the love in which God loves Himself, He loves all creatures, not as creatures but creatures as God. In the love in which God loves Himself, He loves all things. ${ }^{1}$

Another historical way of expressing this (sans the panentheism) is to say that in His life of eternal love, God had creation before Him in His mind. It is that reality through which He wished to express His love (as a theophany or appearance of God) and toward which He could express His love as an other to Himself. Maximus the Confessor (580-662) writes in this fashion: 
God, full beyond all fullness, brought creatures into being not because He had need of anything, but so that they might participate in Him in proportion to their capacity and that He Himself might rejoice in His works (cf. Ps. 104:31), through seeing them joyful and ever filled to overflowing with His inexhaustible gifts. ${ }^{2}$

\section{Creation and Covenant}

According to Christian teaching, such a God who loves His creation everlastingly wishes to be bonded with it. It is for this reason that creation has often been understood as a covenant in Christian theology. By covenant I mean an agreement, a bond, even a contract, which God makes with all humanity, their descendants, and even every living creature (Noah) (Gen. 6:18; 9:9) or with his chosen people (Abraham, Moses) (Gen. 17:4; 34:27) through a chosen representative. The covenant is marked by a sign as a living memorial of the bond. In the case of Noah this was the rainbow (Gen. 9:12-17). In Abraham's case it was circumcision (Gen. 17:9-14), and with the Mosaic covenant the sign was the establishment of the Sabbath/Saturday as the holy day of rest (Exod. 31:12-17). In the covenant God promises He will be faithful. In the case of Noah this faithfulness was a faithfulness directed toward all creation. God promised that He would never destroy the earth by flood. In the case of Abraham this faithfulness was expressed in a promise. He promised He would make him a great nation and make his descendants as many as the stars in the sky and the sand on the seashore and would give them a land from the river of Egypt to the river Euphrates (the Promised Land). Moses in turn received a promise from God that He would make them His people, God's people, "a kingdom of priests and a holy nation" (Exod. 19:6; cf. 1 Pet. 2:9).

But a covenant, a sure bond established by God, requires a certain faithfulness and obedience in return on the part of humanity of God's chosen people. By tradition God gave Noah various commandants and laws he had to follow. In the case of Abraham the sign of the covenant (circumcision) was also the commandment that he and all his offspring were to keep from one generation to another. Moses was given the law found in the Torah (the first five books of the Hebrew Bible or Old Testament), which focused in and around the temple and the rites of sacrifice detailed in Leviticus. Jewish tradition says this was supplemented by the oral law (Mishnah), which we find collected with commentaries in the Talmud. Christians claim, and we see this detailed in the Epistle of the Hebrews, that the fulfillment, transformation, and renewal of the Old Covenant between Israel and Yahweh (i.e., the Mosaic covenant) is given in a New (eternal) Covenant that is sealed by the once for all sacrifice on the cross of Jesus Christ, who is understood as the incarnate divine Word. This sacrifice on the cross is understood to be for humanity's sins, which are envisioned as a "debt" owed to God because 
humanity has violated the law of God in Adam's disobedience in paradise. By the sacrifice of Christ, it is believed, the debt of sins of humanity is paid, the law is fulfilled, and humanity is reconciled with and sanctified by its Creator God. There is then a further theological move. Through human beings graciously having faith in Christ, who fulfilled the law and paid the debt, it is believed that they can share in Jesus's reconciliation with God and are then given a gift of communion and union with Him as "children of God" (Rom. 8:14-17; 1 John 3:1-2).

Now if this eternal New Covenant in Jesus is a once for all reality, and it is eternal, and even if the various covenants, notably the law, were but preparations, even foreshadowings of this true and great and Eternal Covenant, then some theologians have wished to go further and argue that creation, which was formed in Christ as the eternal Word of God (Col. 1:16), must be thought of us founded retroactively and retrospectively on this very New Covenant. So the covenant is not really "new" at all but ever ancient, ever new. ${ }^{3}$ Creation exists, as John Calvin (1509-64) put it, as the "theatre of God's glory." It was formed in anticipation of not only the Fall but also the reconciliation effected between God and humanity through the blood of the cross (Col. 1:20). Karl Barth (1886-1968) extends this idea further when he says that "God's glory is what he does in the world, but in order to do what he does, he must have this theatre, this place and realm-heaven and earth, creation, the creature, man himself." 5 Thus, creation, for Barth, is said to be in the will of God the "External Basis of the Covenant," but, more importantly in the divine decree, the "Covenant is the Internal Basis of Creation." In other words, creation does not exist independently of God's reconciliation of humankind with Himself in Jesus as the Word of God, but it is spiritually instrumental by providing the means by which God might redeem fallen humanity: "Creation is the natural ground for redemption, and redemption is the spiritual ground of creation." 7

Many Christian theologians would have difficulty with this position because they fear it risks conflating creation with covenant and giving the Fall as well as reconciliation with Christ a certain natural necessity. The Incarnation of the Son and Word of God, Jesus Christ, it is argued, is a consequence of the Fall and would not have occurred if Adam had not sinned. In contrast, there is another position that reflects a "minority report" of sorts in the Latin West that is sometimes referred to as "Scotist" (after Duns Scotus, c. 1266-1308) and can be seen in such key early thinkers in the Christian East as Irenaeus of Lyons (c. 130-c. 202) and Maximus the Confessor (580-662). ${ }^{8}$ The teaching is that the Word of God would have become incarnate as Jesus Christ even if Adam had not sinned and no Fall had occurred. The ultimate aim of creation, such thinkers argue, is a personal union of God with His creation. However, there is an even further development of these ideas, controversial for many, as it wishes to think of the relations of the divine persons or hypostases of the Trinity as intrinsically kenotic. The cross itself, it is argued, was written into the foundation of creation as Christ is understood as the Lamb slain spiritually from the foundation of the world (Rev. 
13:8). ${ }^{9}$ The cross is the "watermark of divine love" imprinted on every creature and on nature as a whole, which only comes to light once the historical cross of the Word of God appears implanted in the midst of history and creation, thereby making "worldly being intelligible. . . to receive a foundation in their true transcendent ground." 10 But to understand the link between covenant and creation, we need to further explore the covenantal thinking I am detailing.

\section{Covenant, Creation, and Divine Love}

When the Old Testament speaks of the everlasting love of God (Ps. 103:17; Isa. 54:8; Jer. 31:3), it speaks of a love that is a longsuffering mercy and faithfulness directed toward His chosen people (Ezra 3:11) since it is a freely covenanted or bound "steadfast love" (Ps. 136): "I will make with you an everlasting covenant, my steadfast, sure love for David" (Isa. 55:3). Thus, the nature of the covenant defines and delineates the bounds of the love. In His love, God is free, and this is expressed by the fact that He is "Almighty" both electing or covenanting Himself historically with Noah and all humanity (Gen. 9:8-11), Abraham and His descendants (Gen. 12:1-4; 17:1ff.), and eternally creating and sustaining His creation (Job 40:2). Indeed, God is He who shall be what He shall be toward His chosen people (Exod. 3:14) in His mighty deeds, which they shall experience ("I am the Lord your God, who brought you out of the land of Egypt, to be your God: I am the Lord your God," Num. 15:41) since He is the one who forms light and creates darkness, makes for prosperity and creates calamity, does all things as all things are in His power. Thus, creation itself, in this interpretation of the Old Testament, is an expression of God's love, and that love is a love that binds itself to its creatures, promises itself infallibly to them.

In this perspective, it is God the Creator who initiates the covenant with or elects His chosen people ("I will make my covenant between me and you"; Gen. 17:2), not the people with God as they might make a covenant with the inhabitants of a particular land (Exod. 34:10-17; Jer. 31:31-33). He who made humanity can make them into a people. God, in the mystery of His ways, chooses or elects His people (Ezek. 20:5), not the people God (compare John 15:16). Thus, we may infer that He need not have chosen the people of Abraham, Isaac, and Jacob, just as He need not create the world but did so of His own good will like a man who picks "grapes in the wilderness" (Hosea 9:10). By choosing His people and by enacting mighty deeds in her midst, God makes known to the nations His power and glory (Num. 14:11-16, 21; Isa. 49:3ff.; and see Rom. 9:8ff.). God's people have their status by nature or birth and divine necessity, and they are obligated to freely acknowledge this fact (or not, and die). This initial choice of such a peculiar people ("the Lord set his love upon you and chose you"; Deut. 7:7), however, flies in the face of the fact that they were not a great people but small in number and were even despised. 
Yet even in the Old Testament it is arguable that God can set His love upon someone who is not covenanted to Him as a part of His chosen people, such as Noah (Gen. 6:8-9), Job (Job 1:10), and, in another fashion, the resident alien or stranger and sojourner in the land of Israel (Exod. 22:21). Furthermore, as is noted later by Paul (Rom. 4), God decides to bless Abraham-it is said, due to His faith (and see Heb. 11:8-19) — prior to His covenant with Him (Exod. 12:1ff., 15, 17). In later Hebrew literature, such as the Book of Wisdom, one begins to see a clear universalistic determination for God's love moving from a restricted covenant with His chosen people to the saving love of God for all men insofar as God is not only "merciful to all" (Wisd. 11:23) but is said to "love all things that exist" (Wisd. 11:24) or "love the living" (11:26) since God's "immortal spirit is in all things" (Wisd. 12:1). And why should this be a surprise? For is not God the Creator of all humanity and not just of His chosen people? And does He not do both actions out of free love?

\section{Christ, Creation, Love, and the New Covenant}

God, the writers of the New Testament affirm, has set His love not only on a particular people but on His whole creation, but for these writers this is directly connected to Jesus Christ: "that the world may know that thou hast sent me and hast loved them even as thou hast loved me" (John 17:23). Once again, this love is a covenantal love, but now the meaning of the Old Covenant is said to be revealed as "Christ the power of God and the wisdom of God" (1 Cor. 1:24) or the one in whom there is now a gracious New Covenant of faith. Christ is made known as the "concise word" of the Gospel, which clearly sums up and fulfills the Law and the Prophets' call to God's people to "love the Lord your God with all your heart, and with all your soul, and with all your mind" and to "love your neighbor as yourself" (Matt. 22:37-39). ${ }^{11}$ God, in this theological perspective, has bound Himself eternally to His creation in His eternal perfect "High Priest," Christ, the eternal Word of God, who "through the power of an indestructible life" (Heb. 7:16) serves as "guarantee" in this new "better covenant" (Heb. 7:22) of grace with His Body, the Church, understood to be the new "Israel" or chosen people (Gal. 4:26): "The Lord has sworn and will not change his mind, 'You are a priest forever according to the order of Melchizedek'" (Ps. 110:4; cf. Heb. 7:21).

Christ is understood in Christian teaching not only as the High Priest but as the "image of the invisible God" (Col. 1:15) showing forth the Father God (Heb. 1:3 and John 1:18). Human beings are said to be made in God's image and through this creation are called to be conformed to this image of the Son (Rom. 8:29). Indeed, it is said that Christ is, as the eternal creative Word of God, the one through whom all things and for whom all things have been created (Col. 1:16, John 1:1-3) as He is "before all things" (Col. 1:17). As the Messiah, the Son of David, He exists both before David (Mark 12:35-37, glossing Ps. 110:1) and 
Abraham (John 8:53-59). Thus, as one of the rabbis put it, "The world was created . . . for the sake of the Messiah."12 As the eternal Word of God, Jesus is understood to be the first in everything, in whom "all the fullness of God was pleased to dwell" and God "reconcile[s] to himself all things, whether on earth or in heaven, by making peace through the blood of his cross" (Col. 1:20). In this Christian theological perspective, creation and covenant come together in the Creator, Redeemer, and Word of God-Jesus Christ, the guarantor and living embodiment of the New Covenant.

So from a Christian perspective, creation and Christ, as the guarantor or surety of a better covenant, go together (Heb. 7:22). But if the New Covenant given to humanity with God in Christ is a free gift, it need not have been given, just as one will say that this is the case with creation, whose inner meaning is the covenant. Creation, so Christian teaching holds, need not have been created, just as the New Covenant in Jesus's blood need not have been made. God was free to create the world or not, and to covenant Himself with it or not. He is not necessitated. Creation is contingent. It is a free gift of love. ${ }^{13}$

\section{Genesis: Creation and Covenant}

In Genesis we can see how creation and covenant are thought together in this Christian theological vision. Humanity in the Genesis narrative is the last thing of creation that God forms. He forms creation for humanity, and humankind is given a special mediatorial role over creation through caring, overseeing (“dominion" [Gen. 1:26]), and tending to it as God's representative or viceregent (e.g., naming the animals [Gen. 2:19-20]). In this role he offers it back to God in thanksgiving. God gifts humanity paradise, which is envisioned as a garden he is called to continue to till and to keep and to live upon all its fruits if only he keeps God's commandment to not eat of the tree of the knowledge of good and evil (Gen. 2:15-17). Adam, prior to the Fall, as we can infer from the text of Genesis, had the possibility of knowing God in a direct way and engaging in some sort of dialogue with Him. Thus, we are told that Adam and Eve "heard the sound of the LORD God walking in the garden in the cool of the day" (Gen. 3:8). ${ }^{14}$ Earlier we see that there is also union and communion between Adam and Eve as Eve is taken from Adam; they are one flesh and are naked and are not ashamed (Gen. 2:21-25). Moreover, there is communion, literally communication, between humanity and the animals as God brings the animals to the human being to be named (Gen. 2:19-20) and Adam and Eve, of course, speak with the serpent (Gen. 3:1-6).

That this state of being can be interpreted as covenantal can be seen both in the fact that, having created humanity on the sixth day as the pinnacle of the "very good" creation (Gen. 2:31), God rests on the seventh day (Gen. 2:1-3), which is a foreshadowing of the Sabbath of the Mosaic Covenant (Exod. 16:23-30; 
20:8-11; 31:13-18; Lev. 23). Adam, as humanity, was indeed understood to be in a covenantal bond with his Creator explicitly by other parts of the Old Testament: "For I desire steadfast love and not sacrifice, the knowledge of God rather than burnt offerings. But at Adam they transgressed the covenant; there they dealt faithlessly with me" (Hosea 6:6-7). Furthermore, there is a sort of quasi-priestly or ministerial aspect to this vision of humanity as far as the "priestly" involves mediation; a reverent, grateful, and obedient attitude before God; keeping of His commandments; and care for His holy things. Indeed, the Hebrew terms used for tilling (avad) and keeping (shâmar) the garden in Genesis 2:15 correspond to the terms often used for explaining the Levites' duty to oversee proper worship at the Tabernacle/Temple (e.g., Lev. 18:5; Num. 3:7-8; 4:23-24, 26). The garden is like the Tabernacle (Exod. 40:34-38; Ezek. 43) in which the Lord God dwells and even walks among men (Gen. 3:8). Like the temple, paradise has an east-facing entrance, and, like the mercy seat of the Temple/Tabernacle, it is guarded by cherubim (Gen. 3:24; Ezek. 8:16; Exod. 25:22). ${ }^{15}$ All that was required of humanity for God to remain faithful to bless them in paradise is that they keep the command of God, which is that they not eat of the tree of the knowledge of good and evil (Gen. 2:17). But to be in such a state of obedience is to live in a state of gratitude and thanksgiving.

\section{The Image of God}

The special covenantal bond between God and humanity (and with Him, creation) can be seen above all in the fact that humanity is said to be created in the image and likeness of God (Gen. 1:26-27). There is a long Christian tradition of theological interpretation of the imago Dei. As is well known, the concept, especially in Western Christianity, has often simply been identified with rationality or the mind, which is contrasted with the body. Thus, Augustine of Hippo (354-430), commenting on Genesis 1:26, writes, "From this we are to understand that man was made to the image of God in that part of his nature wherein he surpasses the brute beasts. This is, of course, his reason or mind or intelligence, or whatever we wish to call it." He then links this to Colossians 3:10, which speaks of the need for being renewed in the "spirit of your mind, and put on the new man, who is being renewed unto the knowledge of God, according to the image of his Creator" (echoing Eph. 4:23-24: "created according to the likeness of God"). Augustine concludes from this that humanity has been created in the image of God "not by any features of the body but by a perfection of the intelligible order, that is, the mind when illuminated." "It is perhaps due to this rational interpretation of the image of God that some in the Protestant West have argued that at the Fall the image of God is almost obliterated just as it becomes impossible to know God independently from divine revelation. ${ }^{17}$ Another reason for this 
teaching of the near obliteration of the image of God may be the belief that at the Fall there is no longer any relationship with God possible on the human side without divine intervention, so no sure knowledge of God through that image can take place, so darkened it has become (Rom. 1:19-25). Whatever the case may be, this intellectualized exegesis is but one facet of a more complex exegesis in Christian tradition, and writers often add to the faculty of reason many other aspects, including personhood, creativity, and freedom.

A crucial exegetical issue concerns whether there is any distinction between "image" and "likeness" in Genesis 1:26. The rabbis make no distinction between image and likeness (which are treated as synonyms). ${ }^{18}$ However, a distinction is made early on in Christian tradition, especially since Irenaeus of Lyons in the second century; his exegesis has had a profound influence on the theology of the Christian East or Eastern Orthodoxy in its different forms. ${ }^{19}$ The Christian theological distinction of image (tselem/eikon/imago) and likeness (demut/homoiōsis/ similitudo) possibly originates from the fact that, in the ancient pre-Christian Greek translation of the Septuagint, or LXX (the Bible of the Jewish Diaspora and earliest Christians ${ }^{20}$ ), there is a "kai" (and, also) between the two words ("Let us make man according to our image and likeness" (Gen. 1:26 [LXX]), which was interpreted as a conjunction, whereas this is not the case in Hebrew ("Let us make man in our image, after our likeness").

\section{Image and Likeness}

For Irenaeus, Adam is created by Christ and for Christ in the initial position as body and soul animated by a breath of life from God's Spirit. ${ }^{21}$ He understands "image," as in reference to the Son, as the image of the invisible God (Col. 1:15), whereas "likeness" he understands as in reference to the Spirit, who is referred to as God's "figure." 22 He says that the image of God is located indelibly in the flesh (i.e., the body) and the likeness is seen in the human soul animated by the Spirit. If the person lives toward God, in God's light, then his soul will manifest God's likeness in its breath animating the flesh, as a type of the Spirit. ${ }^{23}$ However, if the person does not live toward God, then the soul's animating life is merely biological, and what remains is the flesh, which is a living corruptible body or body given life by a soul/breath that no longer points beyond itself but points instead to the grave. ${ }^{24}$ Humankind, therefore, had the Spirit resting on it at the beginning. ${ }^{25}$ The Spirit, Irenaeus teaches, vivified humanity bringing "true rationality [veram rationem]." "26 True rationality is to know without coercion that one should obey God and is the freedom to obey Him (life/good) or, out of ignorance, not to obey Him (death/evil). ${ }^{27}$ Thus, the image of God might be understood as free, rational, and creative personhood with the innate possibility of partaking in conscious fellowship with God, and the "likeness of God" is an achieved reality 
when the image, by direct communion with the Person of the Word of God, Jesus Christ, through His spirit, is transformed into the finite image of the divine life.

But we need to return to the Christian connection of Christ with covenant and creation, for at the beginning, before it is claimed that humanity lost the likeness from the Spirit, humankind was said to be stamped for Christ according to His image. Humanity, the teaching holds, was foreordained for recreation or "a second creation by means of His passion which is that [creation] out of death." 28 Jesus Christ, as the eternal Word of God and Creator, not only precedes the created but He precedes the created precisely as its Savior, which means that the created is not only at the end after the Fall but at the beginning prior to the Fall- - understood as that which will be saved. In Irenaeus's words: "Since he pre-existed as one who saves, it was necessary that what might be saved also be created so that the one who saves might not be in vain." 29

\section{Image of God and Free Rational Creativity}

The image and the likeness of God is, for Irenaeus, the almost godlike capacity to be self-determined and to mold one's life and surroundings, in this light either drawing close to God or rejecting Him. ${ }^{30}$ Many in the subsequent Christian tradition will develop Irenaeus's idea, seeing the image and the likeness of God as free, rational, and personal creativity (autexousia). Therefore, to be made in the image and likeness of God is to have a free will or the power to act from within oneself such that one has power over oneself or is self-determining, causa sui. If one has such an internal capacity in the soul, then one can say that the actions that flow from such a free will depend upon oneself or are in our power. ${ }^{31}$ Moreover, we must deliberate about those things that are in our power and can be done. However, such deliberation presupposes that we can choose between at least two possible acts ( $a$ or $b$ ) that are contingent, which is to say that we can just as well do $a$ as we can do its opposite, $b$. Freedom, in this sense, therefore has a direct relation to rationality, for a rational being leads his nature rather than is led by it, as is the case with irrational beings. As Diadochos of Photiki (400-c. 486) puts it: "Free will is the power of a deiform [logikes, rational] soul to direct itself by deliberate choice toward whatever it decides." 32 This sort of freedom prima facie applies absolutely to God who, although He does not deliberate as this implies ignorance, is preeminently free or all-powerful (pantexousios $^{33}$ ) because He has His Being completely from Himself (i.e., aseity) where will and nature are one. Human beings have a form of this freedom, but not absolutely. Besides being subject in their faculty of will to temporality and passion, human beings are always relative to others on whom they depend in their willing for certain choices and circumstances, so they must deliberate since their will is not their essence. 


\section{Humanity as Mediator}

But in what does this free rational and personal creativity consist? At least one strong thread of Christian tradition says it consists of "mediation." By mediation I understand a process of unifying in harmony what is divided, but mediation also involves a sanctifying of creation through caring for it and stewarding its resources, a lifting up of creation to God in gratitude so that He may transform it, and an obedient trusting in God's law, which involves the self-cultivation of the virtues (Col. 3:12-15). The end of this mediatorial vocation is union and communion (as well as communication!) between God and humanity in creation as a created being called to participation in the divine life and to see God face to face in His glory (John 17:24; 1 Cor. 13:12). Humanity, in this perspective, is the pinnacle of creation standing between the spiritual realm and the material realm as belonging to both being an embodied rational soul made for spiritual union with God. This mediatorial role of humanity, involving humanity as a creature in between heaven and earth, called to gratitude and the vision and communion with God, is expressed nicely by Symeon the New Theologian (949-1022) in a poem in the form of a discussion between God and the author:

And so I have said: by my power

I blew a soul into you, (Genesis 2:7)

a soul both logical and rational,

which, as though entering a house,

was united to your body

and took it as an instrument,

the one being appeared out of the two.

I tell you a rational living being,

a human who is double from two

natures inexpressibly;

from a visible body that is

without senses and irrational,

and from an invisible soul

according to my image (Genesis 1:26-27)

both logical and rational

- strange marvel - amidst all things,

between creatures, I say.

Between what creatures?

The material and the immaterial.

For the material creatures are what you see, but the immaterial are angels.

And so between these, I tell you, the double living creature, the human being, who is immaterial in perceptible creation, 


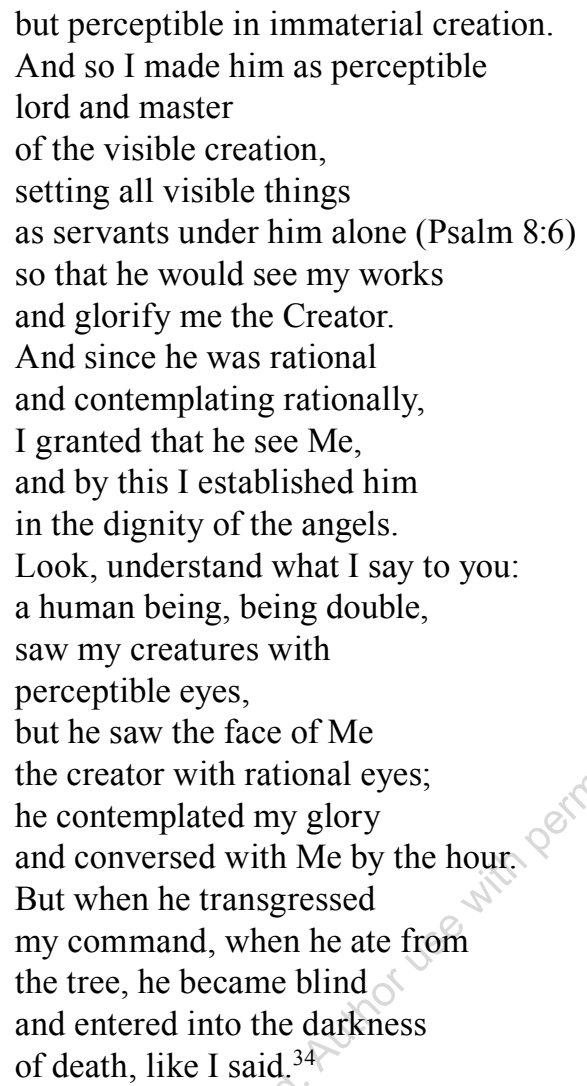

This middle position of humanity "a little lower than God" (Ps. 8:5; or following the LXX: "than the angels"; cf. Heb. 2:7) but above the animal kingdom gives humankind the vocation of having "dominion" over creation (Ps. 8:6 and Gen. $1: 28)$. He is as a sort of king of creation with "glory and honor" or, more properly, viceregent as humanity is crowned by God (Ps. 8:5) and merely rules in God's place. Part of this dominion is for humanity to procreate ("Be fruitful and multiply"; Gen. 1:28; 9:7) and thereby fill the earth, bringing order to creation. Yet to "subdue" creation (Gen. 1:28) or to put all things under one's feet (Ps. 8:6) is not simply to govern or order. It is also a matter of caring for creation, stewarding its resources, and helping it to give up its bounty in a sustainable way. This all comes under the idea of working the world and turning it into an orderly garden reflecting the pattern that exists in heaven and in this way sanctifying it. But in this perspective the vocation of humanity given by God is not only to transform the world into an earthly paradise where all creatures may come to know and praise their Creator (Ps. 148) through different species of ruling and working the world; it is also to bring creation into harmony. It is here I want to expand on the 
idea of "mediation" to further deepen the notion of human creativity within divine creation.

This is a major theme in the work of Maximus the Confessor. He holds that the cosmos, made up of visible and invisible things, is humanity as a macrocosm and conversely that "man made up of soul and body is a world" or microcosm. ${ }^{35}$ Creation in paradise, though indeed "very good" (Gen. 1:31), still needed completion as it was still divided into extremes. Otherwise, why would God have asked humanity to till and keep it? The work of humanity in creation is not mere stewardship but a creative harmonization of the divine creation that was nascent and still capable of growing further into perfection from glory to glory (like humanity itself). These extremes in creation included the divisions of male and female, paradise and the whole world, heaven and earth, intelligible and sensible creation, and the whole of created nature from uncreated nature (i.e., the division of the world from God). Humanity was called "to draw all the extremes into unity" or "mediating through himself all the divided extremes" and in this way to achieve "the mode of their completion . . . and so bring to light the great mystery of the divine plan, realizing in God the union of the extremes which exist among beings, by harmoniously advancing in an ascending sequence from the proximate to the remote and from the inferior to the superior." Creation, according to Maximus, was called in paradise to union with its Creator, and humanity was to be the one in whom and through whom this union was to be achieved. Humanity had this capacity because it was "related to the divided extremes through his own parts." It is precisely because humanity can unite the extremes that it was created last as a "kind of natural bond mediating between the universal extremes through his parts." ${ }^{36}$ And the unity to which it is bringing all things is to gather up all things to the Creator in a union of love where graciously the uncreated was united with the created, "the whole wholly pervading the whole God, and becoming everything that God is, without however identity in essence" as God is "absolutely unique." 37 This is the historic Christian teaching (found in both Christian East and West) of "divinization" or "deification" (theosis) or that humanity might become "participants of the divine nature" (2 Pet. 1:4). ${ }^{38}$ But note the crucial proviso that this is by grace and in no way negates the enduring distinction between God and creation. Even if humanity participates in the divine life, it still remains created, and God still remains uncreated.

\section{Mediation as Praise and Grateful Obedience to God}

But how might this come to pass? Christian teaching holds that this process of unification or mediation to which humanity is called in creation as a free creaturely labor and whose end is union and communion between God and creation can happen only if humanity lives a life of gratitude, trust, and faithful obedience to God's commands. In being obedient to God, one must cultivate the virtues in 
oneself just as Adam cultivated his garden, thereby conforming oneself to the image in which one was created, that of the Son and Word of God (Rom. 8:29), so that one's image might be raised to the divine likeness. This is, quite simply, the acquisition of the Holy Spirit. Such a life was one where humankind lived toward God in lifting up the things of creation to Him in thankfulness as the pinnacle of the whole of creation acknowledging the God whose "eternal power and divine nature, invisible though they are, have been understood and seen through the things he has made" (Rom. 1:20). This is a God who is understood to be "clothed with honor and majesty, wrapped in light as with a garment" (Ps. 104:1-2). In this theological perspective, praising God as long as one lives and has being (Ps. 104:33) is to fulfill the law of God out of sheer gracious and faithful love, thereby drawing all creation toward the Creator in unity: "Let them praise the name of the Lord, for his name alone is exalted; his glory is above earth and heaven" (Ps. 148:13). But such an attitude is said to involve trust. It is a total reliance upon God like the ravens and the lilies of creation that are fed and clothed by their Creator (Luke 12:24, 27-28). It is to strive for the Kingdom, which is to ever be waiting on its Creator like the faithful slaves awaiting their master's return from the wedding banquet (Luke 12:35-38). In short, from a Christian theological perspective, humanity in paradise was called to sum up all things to God in a "sacrifice of praise" (Heb. 13:15) by presenting his body to God "as a living sacrifice, holy and acceptable to God, which is your spiritual worship" (Rom. 12:1). The ungrateful human being is the mortal man since both mortal and immortal life are from God, but immortality is the special gift of the Spirit of God to the human being with a grateful heart.

\section{The Creative Humility of Adam}

Adam was called to cultivate the garden in Eden that God planted for him (Gen. $2: 8,15)$. This consisted both of unifying creation in himself, which we can see in his naming of the animals (Gen. 2:19-20), but he did this precisely through referring all of that creation, including himself as its head, back to God. He lifted it up beyond itself and himself to its source and origin, naming and claiming it as his own and, in giving it his own stamp or name, appropriating it for its Creator, God. But this elevation of creation required both gratitude for the gift of life given to humankind seen in the tree of life upon which they fed and which gave him immortality (Gen. 2:9; 3:22, 24) and above all a rich receptiveness or trust in all of God's commands - that is, a humility or groundedness of heart (Latin, humilis [humble] being related to humus [earth, soil]). Such creative humility of Adam would have allowed him to accept the apparently arbitrary command of not eating of the Tree of the Knowledge of Good and Evil (Gen. 2:16-17). Creation and humanity were mortal, and both could live only through humankind's constant referral of the gifts of the world and himself back to God, by his offering of it as mediator or "priest of creation" to his Creator. ${ }^{39}$ 
Putting this Christian theological perspective slightly differently, the initial vocation of humanity, as summit, summary, king, and microcosm of creation, is for him to consciously, freely, and thankfully appropriate the world and his own nature given to him as a good gift from the Creator and in this way making it both his own and God's own, good for himself and all creation in finding its union with God. When humanity offers up itself and creation to God, it then receives it back transformed into a new humanity and new creation partaking of the divine life, the Spirit, graciously synthesizing in itself the uncreated with the created. In other words, by freely making his own what is gifted to him by God, humanity starts the process of transforming the divine imprint - the image of God-more and more into the likeness of God so that he might have a "share of [the very same] being" 40 that is the divine life, becoming a participant of the divine nature (2 Pet. 1:4). This led Maximus the Confessor and Gregory of Nazianzus (c. 329-90) audaciously to call humanity a "portion of God."41 Thus, the vocation of humanity, according to this Christian perspective, is to be a mediator in creating, accepting, and transforming creation into the divine life of love of God and with it becoming adopted sons and daughters of God "through grace by imitation." 42 This in no way makes a human being a "god" by substance, for the creature is not and never will be its Creator. That would be pantheism, polytheism, and idolatry from a Christian perspective. Indeed, it is precisely because of these reservations that some Protestants reject the teaching of deification, though it is held in different forms by the Roman Catholic and Orthodox churches. It is argued that when humanity makes the divine life his own, when he takes it with gratitude into himself, he then can turn to creation and renew the face of the earth and sanctify it. But this calling of mediation as a free creative praise leading to union of the uncreated and the created was never attained by humanity. ${ }^{43}$

\section{The Fall and the Loss of Humanity's Vocation as Mediator / Priest of Creation}

From a Christian perspective, when human beings disobeyed God, they condemned the world and themselves to death and took it from its calling to be united with God through Himself as mediator. In the death of humanity, the world and humankind itself were tipped back into the ground from which they came. Now begins a process of de-creation, or falling back into the nothingness from which creation came. This state of living death is an existence outside the presence of God and His Holy Word (Matt. 4:4), which brings life eternal. Humanity, it is argued, turned from its vocation of mediation and fell by freely giving in to temptation by Satan. Instead of consciously accepting its own nature as a good and divinizing gift from the hands of God, it instead turned to the world and fed on it, greedily and resentfully partaking of it as if its life depended entirely upon it. In this way, humanity became a slave to both his own nature and his surroundings so that he 
no longer lived through contemplation and communication with God. In the Fall, the human being deluded himself that this participation in the world was his lordship over it and even his liberation from dependence on God such that he went from being a son of God by divine adoption to a self-raised God by autodivinization (Gen. 3:4, 22). Such blindness to reality, existing in a darkness of nonexistence as true life is to exist by having one's sustenance from the hands of God, ultimately leads, Christian teaching holds, to intense misery, suffering, and finally physical death.

In Genesis, Adam and Eve, having disobeyed and knowing this in shame, hide themselves in the trees from God (Gen. 3:8), thereby blocking off encounter between God and themselves. It is as if they go from a state where they stand out from the rest of nature as its crown and summary to a reduction back to the very elements from which they were made. They are alienated from God, from themselves, and from the higher mission of freedom and creativity to which they were called in being formed in the image and likeness of God and asked to obediently follow the law of God. That this is not the normal state of affairs can be seen in God's reaction. He asks them after the Fall when they are hiding from Him, "Where are you?" (Gen. 3:9). They now are conscious of their break with God, their falling away from their true vocation, and Adam answers that when he heard God walking, he was fearful "because I was naked" and hid himself (Gen. 3:10). Once they eat of the fruit, the text says their eyes were opened and knew they were naked and out of shame sewed fig leaves together into aprons to hide their nakedness (Gen. 3:7).

In this passage, we see willful miscommunication between God and humanity on the human being's part. Adam hides himself from God so he can't communicate, and God immediately divines that the basis of their covenant is broken, for He says, "Who told you that you were naked? Have you eaten from the tree of which I commanded you not to eat?" (Gen. 3:11). But this radical fissure, this lack of communicative reciprocity now spreads into all the relationships in creation, and Adam immediately blames Eve (Gen. 3:12). But in blaming her, he tacitly blames God Himself, as he says that the person responsible was "the woman whom you gave to be with me" as if it is God's fault in some sense for having given him someone as a helpmate who led him astray. When God asks Eve, she then blames the serpent (Gen. 3:13) for having deceived her. It is then that we see, with the cursing of the serpent, the beginning of our present order with the animals at odds with both their Creator and with the one whom was their crown, head, and leader upward toward God - that is, humanity (Gen. 3:14-15).

There is in this Christian theological picture no communication, no free intercourse and creativity, no gratitude, and no obedience and striving for perfection and harmony. There is, in short, no mediation and no communion and union with God. Humanity is no longer the priest of creation. All that exists is sorrow, with women being cursed by finding their primary place as brood mares producing children in agony and having their husbands rule over them where presumably 
there was previously a free equality between the sexes, and now there is only an obligation (laying heaviest on women) to continue the human race (Gen. 3:16). Humanity is also cut off from God and from nature as he is no longer allowed to remain in the garden, which he previously tended to harmoniously and in serenity. The earth itself now becomes a curse to Adam, as he must suffer working it (with its thorns and thistles) to survive until he returns to it at death as dust to dust (Gen. 3:17-19).

Having broken their covenant with God, humanity is driven out of paradise (Gen. 3:24), out of a state of communion and union with God, themselves, and the rest of creation. God even has an angel at the entrance who now guards humankind from slipping back in and eating of the tree of life. With the advent of death, God thereby prevents humanity existing in an eternal state of alienation. God, many Christian teachers have claimed, has compassion on humanity and does not want this state of brokenness to continue to exist forever as man's physical death ends it. But there also is the sense here that God, in putting an angel to guard paradise, which was the state of free communion with humanity and free creativity, has permanently acknowledged a break with humanity that only He now can mend. Only He can bring back humanity to paradise and remove the blockage that prevents communion between Him and humankind - that is, the cherubim with the flaming sword (Gen. 3:24). Later the New Testament will describe fallen humanity (man unreconciled to God) as being a slave to sin (Rom. 6:6, 16-23), in "bondage to decay" (Rom. 8:21); and even as an enemy of God (Rom. 5:10) (though it does not say God is our enemy).

\section{Reattaining the Vocation of Mediation / Priest of Creation in Christ as the High Priest of Salvation}

Yet Christian teaching holds that this was not the end of the road, for God does not give up on His creation, the work of His hands. God is not willing that creation should lead a life of eternal death. He mercifully put an end to humanity's eternal life of death in physical death and turned them out of paradise into the world. In His mercy, it is said that God continually drew His creation back to its initial vocation to unite heaven and earth in itself through His covenants, culminating in the New Covenant sealed by God Himself, as the New or Second Adam, the eternal Word, Jesus Christ. God calls creation to live out in the world the "image of Christ" in which they were formed. ${ }^{44}$ In Christ, the path of mediation and of an obedient, gratitude-filled harmonization of creation with God is opened up once again. Having lost in the Fall the mediatorial calling or the priestly garment, humanity/Adam as priest of creation is said to gain it back in Jesus Christ/the Second Adam understood as the eternal "high priest" of salvation (Heb. 3:1; 4:14; 5:8-10; 7:26ff.). ${ }^{45}$ Christian teaching holds that in Christ, as the Second Adam and eternal Word of God, humanity has not merely a creaturely means to partaking of 
the divine life (as was the case with the first Adam) but also a divine means. Christ calls humanity in His "Body" the Church (1 Cor. 12:27) to a life of grateful obedience-becoming a "royal priesthood, a holy nation" (1 Pet. 2:9; cf. Exod. 19:6) lifting up creation on high and caring for it as a gift of love from its Creator. This vocation and ideal is also expressed in terms of adoption as sons (Eph. 1:5) or becoming "children of God" (1 John 3:1; Rom. 8:16). Here the way of egotism is to be put aside, and it is hoped that through the communal work of the Church, there is begun the process of re-achieving in Christ the vocation of mediation. The members of the Church are called as Adam was called before them to work with God as cocreators through obedient and loving praise, thereby uniting what is divided and bringing creation into harmony. Sadly, as can be seen from a quick scan of Christian history and contemporary events, this high vocation and ideal has rarely been taken up by Christians, who most of the time follow the old Adam in living lawless, ungrateful, and disobedient lives in rebellion from their Creator. But such, at least, is the Christian ideal, as some in the tradition have understood it.

\section{A Vision Still Relevant?}

But is this Christian vision of creation as grateful and obedient mediation of divisions, as priests of creation, still relevant in a secular world? Even if we do not accept Maximus's idea of the fivefold division in the cosmos, the world is indeed lacerated by self-inflicted wounds such as an economic system built on the systematic plundering of the earth's resources that is so unjust that less than 1 percent of the population own more wealth than the other 99 percent and "Christian nations" claiming a righteousness from heaven while they wage war against their enemies through television and satellites thousands of miles away. Perhaps a new reappropriation of this ancient Christian vision of divine creation as a theophany of divine love and human participation in that creation as a grateful and obedient priestly mediation may lead a few steps closer toward harmony in this fragmented world.

\section{Notes}

1. Meister Eckhart, Sermon 56, The Complete Mystical Works of Meister Eckhart, trans. Maurice O'C. Walshe (New York: Crossroad, 1991), 293.

2. Maximus the Confessor, 400 Chapters on Love, 3.46 Patrologia Graeca $[P G] 90$, 1029C in The Philokalia, trans. G. Palmer, Philip Sherrard, Kallistos Ware, vol. 2 (London: Faber \& Faber, 1981), 90.

3. Augustine of Hippo, Confessions, trans. Henry Chadwick (Oxford: Oxford University Press, 1998), 10.27.38.

4. John Calvin, Concerning the Eternal Predestination of God, trans. J. Reid (Louisville: Westminster John Knox), 97. 
5. Karl Barth, “A Theological Dialogue," Theology Today 19, no. 2 (July 1962): $171-77$ at 172 .

6. Karl Barth, Church Dogmatics, vol. 3, The Doctrine of Creation, ed. T. F. Torrance and G. W. Bromiley (Edinburgh: T\&T Clark, 1958), part 1, 94ff. and 228ff.

7. Barth, "Theological Dialogue," 172.

8. See Allan B. Wolter, "Duns Scotus on the Predestination of Christ," The Cord: A Franciscan Spiritual Review 5 (December 1955): 366-72; Juniper B. Carol, Why Jesus Christ: Thomistic, Scotistic and Conciliatory Perspectives (Manassas, VA: Trinity Communications, 1986), 120-479; Daniel P. Horan, "How Original Was Scotus on the Incarnation? Reconsidering the History of the Absolute Predestination of Christ in Light of Robert Grossteste," in Heythrop Journal 53, no. 3 (May 2011): 374-91; Irenaeus of Lyons, Adversus omnes Haereses [AH]/Contre les Hérésies, Sources chrétiennes [SC], trans. and ed. Adelin Rousseau et al. (Paris: Cerf, 1965-82), 3.22.3; and Maximus the Confessor, Ad Thalassium 22 (CCSG 7:137-43) and 60 (CCSG 22:73-81) in On the Cosmic Mystery of Christ: Selected Writings from Maximus the Confessor, trans. Paul M. Blowers and Robert Louis Wilken (Crestwood, NY: St. Vladimir's Seminary Press, 2003), 115-18, 123-29.

9. On the cross written into creation, cf. Justin Martyr, Iustini martyris apologiae pro christianis, ed., M. Marcovich, Patristische Texte und Studien [PTS] 38 (Berlin/NY: De Gruyter, 1994), 1. Apol. 60, 116-17 (citing Plato, Timaeus, 36b); Irenaeus of Lyons, AH 5.18.3, SC 153: pp. 244-45 [Armenian fragment]; and Irenaeus of Lyons, On the Apostolic Preaching [Dem.], trans. John Behr (Crestwood, NY: St. Vladimir's Seminary Press, 1997), §34. For Christ as "the Lamb slain from the foundation of the world" (Rev. 13:8), see Sergii Bulgakov, The Lamb of God, abr., trans. and ed. Boris Jakim (Grand Rapids, MI: Eerdmans, 2008); Jürgen Moltmann, The Trinity and the Kingdom, trans. Margaret Kohl (Minneapolis: Fortress Press, 1993 [1980]); and Hans Urs von Balthasar, Mysterium Paschale, trans. Aidan Nichols (San Francisco: Ignatius Press, 2000).

10. Hans Urs von Balthasar, Love Alone Is Credible, trans. D. C. Schindler (San Francisco: Ignatius Press, 2004), 142. Here a comment of Martin Bieler is apposite, echoing Balthasar: "creation is ordered to man and his concrete history, this history, within divine Providence, casts its shadows on all of creation, which exists in solidarity with man. The Cross and the Resurrection are from the very beginning the watermark the Creator has imprinted on creation, but he has done so in order to make everything finally serve the fulfillment that comes with the revelation of the freedom of the glory of God's children." Martin Bieler, "Creation, Evolution, and the Drama of Redemption," Communio 33, no. 2 (Summer 2006): 305-9 at 308.

11. "Concise word": Irenaeus of Lyons, Dem., §87, p. 93.

12. Sanhedrin 98b, trans. Joseph Shachter and H. Freedman, ed. Isidore Epstein (London: Soncino Press, 1936), 668; See this text cited in Benedict XVI, "General Audience Address of 7 September 2005," Libreria Editrice Vaticana, http://w2.vatican.va/content /benedict-xvi/en/audiences/2005/documents/hf_ben-xvi_aud_20050907.html.

13. For further discussion, see Brandon Gallaher, Freedom and Necessity in Modern Trinitarian Theology (Oxford: Oxford University Press, 2016).

14. Irenaeus of Lyons (Dem. 12) and Theophilus of Antioch (To Autolycus 2.22) interpret this passage in reference to the Son or Logos walking and talking to Adam in the garden prefiguring the coming of Christ who dwells among men. Theophanies of God were often interpreted in early Patristic writers as being of the Logos or Son of God 
(Irenaeus, Dem. 44-45) as "the Father is the invisible of the Son, but the Son is the visible of the Father" (AH 4.6.6).

15. See Gordon Wenham, Genesis 1-15 (Nashville: Thomas Nelson, 1987), 67, 87, and 90 .

16. Augustine of Hippo, The Literal Meaning of Genesis, vol. 1, 3.20.30, trans. John Hammond Taylor, Ancient Christian Writers no. 41 (New York: Paulist Press, 1982), 96.

17. See John Calvin, Institutes of the Christian Religion, 2 vol., trans. Ford Lewis Battles, ed. John McNeill (Philadelphia: Westminster, 1960), 1:1.15.3-4, 186-90, and 1:3.7.6, 696-97.

18. See Genesis Rabbah: The Judaic Commentary to the Book of Genesis: A New American Translation, vol. 1: Parashiyyot One through Thirty-Three on Genesis 1:1 to 8:14, trans. and ed. Jacob Neusner (Atlanta: Scholars Press, 1985), Parashah Eight, 10-11, and Genesis 1:26.

19. See Irenaeus of Lyons, $A H$ 5.6.1 and 5.16.1-2.

20. See T. M. Law, When God Spoke Greek: The Septuagint and the Making of the Christian Bible (New York: Oxford University Press, 2013).

21. Irenaeus of Lyons, $A H$ 5.1.3 and 12.1.

22. On "image": Irenaeus of Lyons, Dem. 22; and Irenaeus of Lyons, $A H$ 5.16.2; and cf. 2 Cor. 4:4. On "likeness": figuratio (AH 4.7.4). Ante-Nicene Fathers translates as similitude; cf. ibid., 5.6.1.

23. Ibid., 3.24.1.

24. Ibid., 5.6.1.

25. Ibid., 4.33.15.

26. Ibid., 4.4.3.

27. Irenaeus of Lyons, Dem. 11, AH4.4.3 and 37.1-5.

28. Ibid., 5.23.2.

29. "Cum enim praeexsisteret saluans, oportebat et quod saluaretur fieri, uti non vacuum sit saluans" (ibid., 3.22.3 (SC 211: pp. 438-39); Cf. Martin Luther: "He created us for this very purpose, to redeem and sanctify us." Martin Luther, Large Catechism, 64, Book of Concord (Philadelphia: Fortress, 1959), 419.

30. See Basil of Caesarea, "Homily on Psalm 48," 8, Exegetic Homilies, trans. Agnes Way, The Fathers of the Church, 46 (Washington, DC: Catholic University of America Press, 1963), 324-25 [PG 29b.449B-C]; and Maximus the Confessor, The Disputation with Pyrrhus, trans. Joseph Farrell (South Canaan, PA: St. Tikhon's Seminary Press, 1990), 25 [Disput s Pirrom, ed. and trans. D. Pospelov (Moscow: Khram Sofii Premudrosti Bozhiei, 2004), 304C-D, 170-71]; and commentary at William Telfer, "Autexousia," Journal of Theological Studies 8, no. 1 (1957): 123-28.

31. John of Damascus, St. John of Damascus: Writings, 2.26, trans. Frederic H. Chase, FC 37 (Washington: Catholic University of America Press, 1981), 257 [PTS 12; 40, 97-98]; On (in)voluntary acts, see Aristotle, Nicomachean Ethics, 3.1.1109b 30ff.

32. Diadochos of Photiki, "On Spiritual Knowledge and Discrimination: 100 Texts," 5, in The Philokalia, trans. G. Palmer, Philip Sherrard, and Kallistos Ware, vol. 1 (London: Faber \& Faber, 1979), 254 [SC 5, 5, 86].

33. See Adamantius, Dialogue on the True Faith in God [de recta in Deum fide], 837e/ III, 9, trans. Robert A. Pretty, ed. Garry W. Trompf (Leuven: Peeters, 1998), 118-19.

34. Symeon the New Theologian, Divine Eros: Hymn of St Symeon the New Theologian, Hymn 53, 11, trans. and ed. Daniel K. Griggs (Crestwood, NY: St. Vladimir's Semi- 
nary Press, 2010), 95-144, 375-76; cf. Anestis G. Keselopoulos, Man and the Environment: A Study of St Symeon the New Theologian, trans. Elizabeth Theokritoff (Crestwood, NY: St. Vladimir's Seminary Press, 2001).

35. Maximus the Confessor, Mystagogy, 7, in Maximus the Confessor: Selected Writings, trans. and ed. George C. Berthold (New York: Paulist Press, 1985), 196 (PG 91.684D-685A). Here see Lars Thunberg, Microcosm and Mediator: Theological Anthropology of Maximus the Confessor (Chicago: Open Court, 1995).

36. Maximus, On Difficulties in the Church Fathers: The Ambigua 2:41, ed. and trans. Nicholas Constas (Cambridge, MA: Harvard University Press, 2014), 102-5 (PG 91.1304D-1305B).

37. Ibid., 2:41, 105, 109 ( $P G 91.1305 \mathrm{C}, 1308 \mathrm{~B})$.

38. See Irenaeus of Lyons, $A H$ Athanasius of Alexandria, De Incarnatione in Contra Gentes and De Incarnatione 54, II.11-12, ed. and trans. Robert W. Thomson (Oxford: Clarendon, 1971), 268-69; Gregory of Nyssa, The Great Catechism, chap. 25 (PG 45.65C68A); Augustine of Hippo, Sermons (184-229Z) on the Liturgical Seasons, WSA III/6, trans. Edmund Hil, ed. John E. Rotelle 192.1.1 (New Rochelle, NY: New City Press, 1993), 47; Expositions of the Psalms, 33-50, WSA III/16, trans. and ed. Maria Boulding and John E. Rotelle, 49.1.2 (Hyde Park, NY: New City Press, 2000), 381; and Maximus the Confessor, Ad Thalassium 22 [CCSG 7:137-43], 115-18. For commentary, see Norman Russell, The Doctrine of Deification in the Greek Patristic Tradition (Oxford: Oxford University Press, 2004); and David Vincent Meconi, The One Christ: St. Augustine's Theology of Deification (Washington, DC: Catholic University of America Press, 2013).

39. See John Zizioulas, The Eucharistic Communion and the World, ed. Luke Ben Tallon (London: T\&T Clark, 2011), 133-41.

40. See Origen of Alexandria, On First Principles, 1.3.6, trans. G. Butterworth (Gloucester: Peter Smith, 1973), 35 [SC 252, 154-55, 1.161]; Pseudo-Dionysius the Areopagite, Divine Names, in Pseudo-Dionysius: The Complete Works, trans. Colm Luibheid, Paul Rorem (New York: Paulist Press, 1987), 5.6 [PTS 33; 184, 11.17-21], 99; and Thomas Aquinas, The Summa Contra Gentiles of St Thomas Aquinas, 3a.20, trans. English Dominicans (New York: Benziger Brothers, 1924), 38.

41. Maximus the Confessor, Ambiguum 7.pref. [PG 1068D], 75ff. (exegeting Gregory Nazianzus, Or. 14.7 [PG 35.865C]).

42. Cyril of Alexandria, Commentary on John, I.9, 89c, in Norman Russell, Cyril of Alexandria (London: Routledge, 2000), 101.

43. It is not surprising that we see in some of the Christian Fathers the teaching that in time God would have given the human being the Fruit of the Knowledge of Good and Evil. Humankind's sin was then presumption or not waiting on God for His gift of perfection (deification) but seizing it of his own accord before his appointed time (See Ephrem the Syrian, Hymns on Paradise, Hymn XII.3, trans. Sebastian Brock (Crestwood, NY: St. Vladimir's Seminary Press, 1990), 161; Section 2, §23, The Commentary on Genesis in Hymns on Paradise, 214; and Gregory Nazianzus, Or. 45.8 (Second Paschal Oration).

44. Irenaeus of Lyons, Dem. $\$ 22$; and see 2 Cor. 4:4.

45. On "priestly garment": "ab Spiritu sanctitatis stolam" $(A H 3.23 .5$ and compare 4.20.11). 